Gut, 1968, 9, 117-124

\title{
Gastric cancer associated with gastroenterostomy and partial gastrectomy
}

\author{
F. PYGOTT AND V. L. SHAH \\ From the Central Middlesex Hospital, London
}

Gastric surgery as a definitive method of treatment for simple peptic ulcer has been practised on an increasing scale over the last 50 or 60 years. Despite operation complete relief may not result and the patient may present at widely varying periods afterwards with new or recurrent symptoms. Increasing age brings an increased risk of gastric cancer but the onset of this occasional sequel may be obscured by symptoms which may have followed more immediately after operation. The purpose of this paper is to describe our experiences in the radiological diagnosis of gastric cancer in 13 patients who had already had gastric surgery for simple peptic ulceration, eight having had a gastroenterostomy and five a partial gastrectomy.

Records of individual cases of gastric cancer following gastroenterostomy appear in the literature from the mid 1920s onwards. Beatson (1926) reported a case occurring 10 years after this operation. Owen's case (1926) occurred at a similar interval after operation and radiological examination showed a small stoma and irregular pyloric antrum due to the advanced antral carcinoma. Hurst and Stewart (1929) reported another early example. Singer (1932) reported a case of carcinoma of the gastroenterostomy stoma and collected three similar cases from the literature. Crohn (1927), writing on affections of the stomach, quoted Bamberger's series of 1,025 patients who had had gastroenterostomy in whom 22 cases of carcinoma of the stomach developed later. Since this operation is often performed without biopsy of the lesion an already existing carcinoma cannot be entirely excluded, though a long interval between operation and the development of recognizable cancer makes this less likely. In practice a patient who has had only a palliative gastroenterostomy for gastric cancer surviving for five years is rare, but occasional exceptions occur, as for example in Pygott's (1964) recorded case of survival for seven years.

Gray and Lofgren (1948) reviewed a 10-year series of 825 partial gastrectomies performed at the Mayo Clinic a variable period after gastroenterostomy for gastric or duodenal ulcer. Eleven cases of gastric cancer were encountered among the patients previously operated on for duodenal ulcer, an average of 15 years after the gastroenterostomy. There were six cases of gastric cancer among those operated upon for gastric ulcer but five of the gastric ulcer cases were operated upon within two years of gastroenterostomy so it may be that the original diagnosis of simplicity was incorrect. Freedman and Berne (1954) record a collected series of 55 patients with gastric carcinoma of the gastroduodenal stoma and added a further three of their own. In thcir series 24 primary operations were for duodenal ulcer and 14 were for gastric ulcer, the reason being unknown in the remainder. The average interval between gastroenterostomy and the recognition of gastric cancer in their series was $\mathbf{1 7}$ years and in their personal cases the interval was from 26 to 40 years. Helsingen and Hillestad (1956) were able to obtain information about 229 patients who had had a partial gastrectomy for simple peptic ulcer from 10 to 35 years before: 11 cases of cancer of the gastric stump occurred at an interval of 20 years and 10 of these followed resection for gastric ulcer and only one for duodenal ulcer. They comment that the observed rate of carcinoma in gastric ulcer patients is about three times the expected rate and that in duodenal ulcer patients it is approximately the normal rate. De Jode (1961) reported 19 cases of gastric cancer following gastric operations, 12 following gastroenterostomy and seven partial gastrectomy in the 10 years $1949-58$ at The London Hospital. Nine of his 12 gastroenterostomies were for duodenal ulcer and so were four of the seven partial gastrectomies; the remaining operations were for gastric ulcer. The interval between operation and gastric cancer was from 18 to 37 years in cases of gastroenterostomy and from two to 36 years after partial gastrectomy. In two cases occurring less than five years following the latter operation one patient had originally a duodenal ulcer and the other a gastric ulcer but in both the carcinoma was at the cardia and remote from the orig- 
inal site of ulceration. Only nine out of 19 of De Jode's cases were operable and six of these died within three years. He comments that radiological diagnosis may be difficult as the contracted neoplastic antrum may result in a gastroenterostomy simulating the appearance of a partial gastrectomy.

Liavaag (1962) reviewed 616 patients who had had a partial gastrectomy 15 years or more before. Twenty-five had developed gastric cancer. He concluded that in patients operated upon for gastric ulcer the cancer incidence in the residual stomach is reduced to an extent that approaches the incidence in the general population but that in those operated upon for duodenal ulcer the incidence increases to an extent that also approaches the rate for the general population. Packovich and Beck (1962) collected 53 cases of gastric cancer following gastroenterostomy at an average interval of 17 years, and they comment that in nearly half the patients the carcinoma was limited to the area of the gastroenterostomy.

Series of cases associating gastroenterostomy or partial gastrectomy with supervening gastric cancer have been reported by Debray, Roux, Chevillotte, and Segal (1950) seven cases; by Harbitz (1952) four cases; by Leren (1953) five cases; by Ryan and Beal (1957) seven cases; by Côté, Dockerty, and Cain (1958) 17 cases, of which five followed partial gastrectomy and 12 simple excision of the ulcer and gastroenterostomy; Berry, Lee, and Coffey (1959) three cases; Berkowitz, Cooney, and Bralow (1959) eight cases; Aronson and Darling (1959) a collected series of 19 cases; Capos and Hyman (1961) two cases; and Coffey and Cardenas (1964) five cases.

TABLE

CASE SUMMARIES

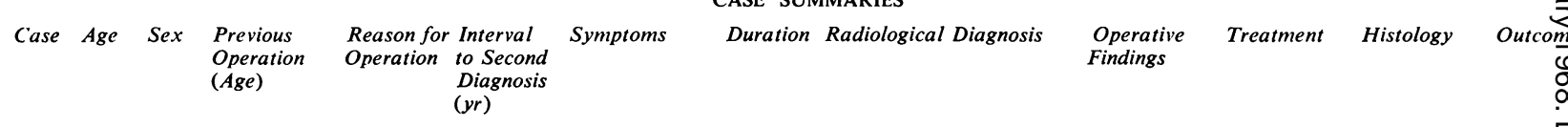

\begin{tabular}{|c|c|c|c|c|c|c|c|c|c|c|c|}
\hline $\begin{array}{l}1 \\
\text { H.H. }\end{array}$ & 72 & $\mathbf{M}$ & $\begin{array}{l}\text { Gastro- } \\
\text { enterostomy } \\
\text { (64) }\end{array}$ & $\begin{array}{l}\text { Duodenal } \\
\text { ulcer }\end{array}$ & 8 & $\begin{array}{l}\text { Abdominal } \\
\text { pain, weight } \\
\text { loss, anorexia }\end{array}$ & $6 \mathrm{mth}$ & $\begin{array}{l}\text { Barium enema: thick- } \\
\text { walled stomach, ? } \\
\text { cancer. Barium meal: } \\
\text { cancer body of stomach, } \\
\text { normal cap }\end{array}$ & $\begin{array}{l}\text { Extensive } \\
\text { carcinoma } \\
\text { body of } \\
\text { stomach } \\
\text { with gland- } \\
\text { ular } \\
\text { involvement } \\
\text { Not done }\end{array}$ & $\begin{array}{l}\text { Subtotal } \\
\text { Polya } \\
\text { gastrectomy }\end{array}$ & $\begin{array}{l}\text { Anaplastic } \\
\text { adeno- } \\
\text { carcinoma } \\
\text { (grade 3-4) }\end{array}$ \\
\hline
\end{tabular}

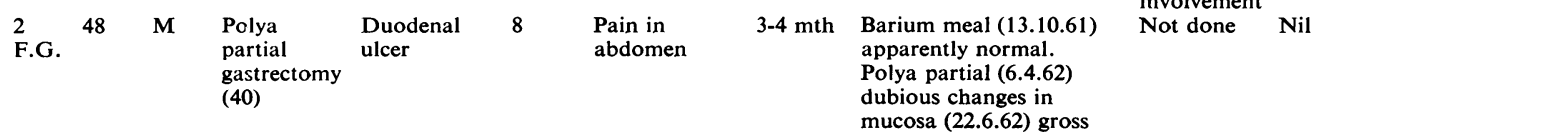

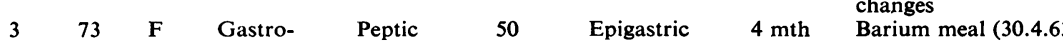

$\begin{array}{llll}3 & 73 & \text { F } & \begin{array}{l}\text { Gastro- } \\ \text { enterostomy }\end{array} \\ \text { M.H. } & & \text { Peptce }\end{array}$ (23)

$\begin{array}{lllll}4 & 69 & \mathbf{M} & \begin{array}{l}\text { Polya } \\ \text { partial }\end{array} & \begin{array}{l}\text { Duodenal } \\ \text { ulcer }\end{array}\end{array}$
gastrectomy

Epigastric $4 \mathrm{mth}$
pain and
vomiting,
temporary
improvement,
recurrence
in $1 \frac{1}{2}$ years
$\begin{aligned} & \text { Belching, } \\ & \text { weight loss }\end{aligned}$
and vomiting

\begin{tabular}{|c|c|c|c|c|}
\hline $\begin{array}{l}5 \\
\text { A.S. }\end{array}$ & 61 & $\mathbf{M}$ & $\begin{array}{l}\text { Polya } \\
\text { partial } \\
\text { gastrectomy } \\
\text { (31) }\end{array}$ & $\begin{array}{l}\text { Gastric } \\
\text { ulcer }\end{array}$ \\
\hline $\begin{array}{l}6 \\
\text { R.W. }\end{array}$ & 80 & $\mathbf{F}$ & $\begin{array}{l}\text { Polya } \\
\text { partial } \\
\text { gastrectomy } \\
(50)\end{array}$ & $\begin{array}{l}\text { Gastric } \\
\text { ulcer }\end{array}$ \\
\hline $\begin{array}{l}7 \\
\text { C.D. }\end{array}$ & 60 & $\mathbf{M}$ & $\begin{array}{l}\text { Gastro- } \\
\text { enterostomy } \\
\text { (42) }\end{array}$ & $\begin{array}{l}\text { Duodenal } \\
\text { ulcer }\end{array}$ \\
\hline
\end{tabular}
(42)

\section{reported as stomach} ulcer: retrospect dubious antral changes. (4.5.65) Gross antral deformity, carcinoma

14.11.58 reported as
Polya partial gastrectomy
with gross delay in
emptying: retrospect
slight irregularity above
resection site

$\begin{array}{lll}\begin{array}{l}\text { Anorexia, } \\ \text { weight loss, } \\ \text { abdominal } \\ \text { pain, fainting } \\ \text { attacks }\end{array} & 6 \mathrm{mth} & \begin{array}{l}\text { 13.7.57 Destruction and } \\ \text { filling defects in whole } \\ \text { of stomach remnant }\end{array} \\ \begin{array}{l}\text { Anaemia, } \\ \text { Abdominal } \\ \text { pain, anorexia }\end{array} & 8 \mathrm{mth} \text { mth } & \begin{array}{l}\text { Grso } \\ \text { Grossly contracted and } \\ \text { Carcinoma }\end{array} \\ \begin{array}{l}\text { Abdominal } \\ \text { pain, weight } \\ \text { loss, anorexia }\end{array} & 6 \mathrm{mth} & \begin{array}{l}\text { 10.8.59. Large shallow } \\ \text { ulcer crater in lower } \\ \text { body of stomach, distal } \\ \text { to the stoma. } \\ \text { Carcinoma }\end{array}\end{array}$

Solid lesion no metastases

Hard ulcerted mas at area of anastomosis eriorly to colon

Biopsy cervical gland adenocarcinoma Not operated

Leather-

bottle type carcinoma

with near

total

involvement of stomach.

Pancreas also involved
Subtota gastrectomy carcinoma and gastro- (grade 3-4) jejunostomy

Died 2O $m$ th af operation

Died $2 \vec{\sigma}$ days aftrer last barium meal

Last sê़ी $2 \mathrm{mth}$ after operatiकू 'extremely well'

Gained weight 염 felt better for 2 md postoperatikgly. Died afer 7 mth Inoperable Anaplastic No traces
adenocarcinoma (grade 4)

Necropsy: adenocarcinoma Died 10 (well differentiated) with after $\frac{1}{(2)}$ widespread secondary diagnofts deposits) Only biopsy Anoplastic carcinoma

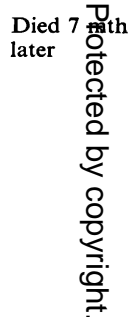


Kühlmayer and Rokitansky (1954), in a review of necropsy findings in patients who had had a subtotal gastric resection for supposed benign gastric or duodenal disease 10-25 years before, give an incidence of $11 \%$ of gastric cancer in the stump of the stomach, about twice that of the expected incidence of gastric cancer. Krause (1958), in a follow-up study of 361 patients who had had a partial gastrectomy for ulcer between 1905 and 1933, had a similar experience. Twenty-five cases of gastric cancer occurred in their series instead of an expected total of just over 11, at an average time interval after the partial gastrectomy of $\mathbf{2 4 \cdot 3}$ years.

\section{REPORTED SERIES}

Our series is made up of 11 men and two women with an age range of 48 to 81 years and an average age of 66. Gastroenterostomy had been performed in eight patients, in six of whom a duodenal ulcer was the stated reason; in another it was the probable reason; and in the eighth patient the reason given was 'peptic ulcer'. Partial gastrectomy had been performed in five cases, in three instances for duodenal ulcer and in two for gastric ulcer. The age at the time of the original gastric operation varied from 22 to 64 years with an average age of 40 years. The interval between operation and diagnosis of gastric cancer was eight to 50 years with an average of 26 years.

Symptoms related to the neoplastic gastric lesion had been present at the time of final diagnosis for a few weeks to two years with an average of six months.

\section{TABLE-continued}

\begin{tabular}{|c|c|c|c|c|c|c|c|c|c|c|c|c|}
\hline \multirow[b]{2}{*}{ Case } & \multirow[b]{2}{*}{ Age } & \multirow[b]{2}{*}{ Sex } & \multirow[b]{2}{*}{$\begin{array}{l}\text { Previous } \\
\text { Operation } \\
\text { (Age) }\end{array}$} & \multirow[b]{2}{*}{$\begin{array}{l}\text { Reason for } \\
\text { Operation }\end{array}$} & \multirow[b]{2}{*}{$\begin{array}{l}\text { Interval } \\
\text { to Second } \\
\text { Diagnosis } \\
\text { (yr) }\end{array}$} & \multirow[b]{2}{*}{ Symptoms } & \multicolumn{2}{|c|}{ CASE SUMMARIES } & \multirow[b]{2}{*}{$\begin{array}{l}\text { Operative } \\
\text { Findings }\end{array}$} & \multirow[b]{2}{*}{ Treatment } & \multirow[b]{2}{*}{ Histology } & \multirow[b]{2}{*}{ Outcome } \\
\hline & & & & & & & Duration & Radiological Diagnosis & & & & \\
\hline $\begin{array}{l}8 \\
\text { G.C. }\end{array}$ & 80 & $\mathbf{M}$ & $\begin{array}{l}\text { Gastro- } \\
\text { enterostomy } \\
\text { (40) }\end{array}$ & $\begin{array}{l}\text { Duodenal } \\
\text { ulcer }\end{array}$ & 40 & $\begin{array}{l}\text { Abdominal } \\
\text { pain, melaena, } \\
\text { vomiting }\end{array}$ & $1 \mathrm{mth}$ & $\begin{array}{l}\text { 26.7.57. Neoplastic ulcer } \\
\text { in pyloric end of stomach } \\
\text { Duodenal deformity }\end{array}$ & $\begin{array}{l}\text { Operation } \\
\text { contra- } \\
\text { indicated } \\
\text { and so } \\
\text { discharged } \\
\text { from } \\
\text { hospital }\end{array}$ & & & \\
\hline $\begin{array}{l}9 \\
\text { J.G. }\end{array}$ & 81 & $\mathbf{M}$ & $\begin{array}{l}\text { Gastro- } \\
\text { enterostomy } \\
\text { (31) }\end{array}$ & $\begin{array}{l}\text { Duodenal } \\
\text { ulcer }\end{array}$ & 50 & $\begin{array}{l}\text { Abdominal } \\
\text { distension, } \\
\text { vomiting, } \\
\text { loss of } \\
\text { appetite } \\
\text { and weight }\end{array}$ & $2 \mathrm{mth}$ & $\begin{array}{l}\text { Irregular contraction of } \\
\text { distal part of stomach. } \\
\text { No visible gastro- } \\
\text { enterostomy (involved). } \\
\text { Fluid retention. } \\
\text { Carcinoma }\end{array}$ & $\begin{array}{l}\text { Pyloric } \\
\text { carcinoma } \\
\text { with } \\
\text { secondary } \\
\text { deposits }\end{array}$ & Inoperable & $?$ & $\begin{array}{l}\text { Died } 1 \text { week } \\
\text { later }\end{array}$ \\
\hline $\begin{array}{l}10 \\
\text { J.R. }\end{array}$ & 67 & $\mathbf{M}$ & $\begin{array}{l}\text { Gastro- } \\
\text { enterostomy } \\
\text { (47) }\end{array}$ & $\begin{array}{l}\text { Duodenal } \\
\text { ulcer }\end{array}$ & 20 & $\begin{array}{l}\text { Abdominal } \\
\text { pain and } \\
\text { vomiting }\end{array}$ & $2 \mathrm{yr}$ & $\begin{array}{l}30.11 .60 \text {, stomal ulcer; } \\
18.1 .61 \text {, coarse mucosa } \\
\text { of stomach; } \\
20.11 .61 \text {, large ulcer } \\
\text { on gastric side of stoma, } \\
\text { with contraction of body } \\
\text { of stomach }\end{array}$ & $\begin{array}{l}\text { Confirmed } \\
\text { gastric } \\
\text { ulcer, } \\
\text { evidence of } \\
\text { old duodenal } \\
\text { ulcer }\end{array}$ & $\begin{array}{l}\text { Polya } \\
\text { partial } \\
\text { gastrectomy }\end{array}$ & $\begin{array}{l}\text { Chronic } \\
\text { gastric } \\
\text { ulcer with } \\
\text { superficially } \\
\text { spreading } \\
\text { carcinoma }\end{array}$ & 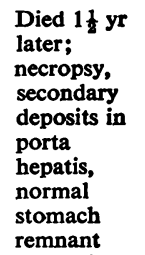 \\
\hline $\begin{array}{l}11 \\
\text { A.C. }\end{array}$ & 65 & $\mathbf{M}$ & $\begin{array}{l}\text { Partial } \\
\text { gastrectomy } \\
\text { (51) }\end{array}$ & $\begin{array}{l}\text { Duodenal } \\
\text { ulcer }\end{array}$ & 14 & $\begin{array}{l}\text { Indigestion, } \\
\text { pain in epi- } \\
\text { gastrium } \\
\text { radiating to } \\
\text { back and } \\
\text { throat, } \\
\text { dysphagia and } \\
\text { vomiting }\end{array}$ & $\begin{array}{l}3 \mathrm{mth} \\
2 \mathrm{mth} \\
1 \mathrm{mth}\end{array}$ & $\begin{array}{l}8.8 .65 \text {, normal }-10.65 \text {, } \\
\text { peptic oesophagitis }\end{array}$ & $\begin{array}{l}\text { Extensive } \\
\text { carcinoma } \\
\text { of lesser } \\
\text { curve with } \\
\text { secondary } \\
\text { deposits in } \\
\text { liver }\end{array}$ & $\begin{array}{l}\text { Moussen- } \\
\text { Barbu } \\
\text { tube } \\
\text { passed }\end{array}$ & $\begin{array}{l}\text { Primary } \\
\text { adeno- } \\
\text { carcinoma } \\
\text { fairly well } \\
\text { differentiated }\end{array}$ & $\begin{array}{l}\text { Died after } \\
15 \text { days; } \\
\text { necropsy } \\
\text { confirmed }\end{array}$ \\
\hline $\begin{array}{l}12 \\
\text { K.H. }\end{array}$ & 63 & $\mathbf{M}$ & $\begin{array}{l}\text { Gastro- } \\
\text { enterostomy } \\
\text { (36) }\end{array}$ & $\begin{array}{l}\text { Duodenal } \\
\text { ulcer }\end{array}$ & 27 & $\begin{array}{l}\text { Hepatomegaly, } \\
\text { no other } \\
\text { symptoms }\end{array}$ & & $\begin{array}{l}\text { 12.12.57, irregularity } \\
\text { of lesser curve just } \\
\text { below angulus; } \\
12.2 .65 \text {, 'Pouch form- } \\
\text { ation, partial } \\
\text { gastrectomy', in } \\
\text { retrospect, gastro- } \\
\text { enterostomy, carcinoma }\end{array}$ & Nil & - & $\begin{array}{l}\text { We differ- } \\
\text { entiated } \\
\text { adeno- } \\
\text { carcinoma, } \\
\text { becoming } \\
\text { pleomorphic } \\
\text { on necropsy }\end{array}$ & $\begin{array}{l}\text { Died } 2 \text { mth } \\
\text { after } \\
\text { operation, } \\
\text { necropsy } \\
\text { confirmed }\end{array}$ \\
\hline $\begin{array}{l}13 \\
\text { L.w. }\end{array}$ & 47 & $\mathbf{M}$ & $\begin{array}{l}\text { Gastro- } \\
\text { enterostomy } \\
\text { (22) }\end{array}$ & $\begin{array}{l}\text { Duodenal } \\
\text { ulcer }\end{array}$ & 25 & $\begin{array}{l}\text { Pain, loss of } \\
\text { weight, small, } \\
\text { hard epigastric } \\
\text { mass }\end{array}$ & $\begin{array}{l}\text { Off and } \\
\text { on } 2 \text { yr }\end{array}$ & $\begin{array}{l}\text { Extensive carcinoma of } \\
\text { stomach involving whole } \\
\text { of stomach and gastro- } \\
\text { enterostomy }\end{array}$ & $\begin{array}{l}\text { Not } \\
\text { operated } \\
\text { upon }\end{array}$ & $\begin{array}{l}\text { Died } 2 \text { wk } \\
\text { later in } \\
\text { hospital }\end{array}$ & & \\
\hline
\end{tabular}


Seven of the patients were operated upon but in three of these only laparotomy was possible. Four patients had a subtotal abdominal gastrectomy performed; one patient is alive a year after the gastrectomy and is apparently well; but the other three are dead and the longest survival was only 18 months. The details of individual cases are recorded in the Table.

\section{RADIOLOGICAL DIAGNOSIS}

Barium meal examination was carried out on all patients in the series. In six patients the initial examination was correctly interpreted as showing a neoplastic lesion of the stomach. In one of these correctly diagnosed patients the first examination requested clinically was a barium enema (case 1 , Figs. 1 and 2), and the abdominal films taken during this examination showed the air relief of a thickwalled stomach suggesting a carcinoma of the body of the stomach, a diagnosis which the barium meal examination confirmed. In two patients (cases 4 and 12, Fig. 3) the interpretation of the initial examination should have been taken further at the time of reporting and the examination showed virtually conclusive evidence of carcinoma. In two patients (cases 3 and 10, Figs. 4 and 5) the initial barium meal examination was interpreted as showing a stomal ulcer (in case 3 there were dubious changes in the stomach). In two instances (cases 2 and 11, Figs. 7, 8, and 9) the examination was regarded as showing a normal Polya partial gastrectomy; in case 2 a repeat examination six months later showed doubtful changes in the stomach remnant and a third examination eight months after the first showed grossly abnormal appearances. In case 3 a second barium meal examination two years later than the first showed gross carcinomatous deformity of the gastric antrum yet gastric resection was possible and at operation there was no evidence of local or distal metastases, and this patient is at present very well but the operation was only a year ago. In case 10 (Fig. 6), following a primary diagnosis of stomal ulcer, a second barium meal two months later showed only a coarse gastric mucosal pattern and a third a year later showed a large ulcer on the gastric side of the gastroenterostomy stoma with contraction of the body of the stomach. Laparotomy in this patient confirmed the presence of a 'gastric ulcer' with evidence of an old duodenal ulcer and a partial gastrectomy was performed. Histology showed a chronic gastric ulcer with superficially spreading carcinoma, and necropsy 18 months later showed secondary deposits in the porta hepatis and a normal gastric remnant. In case 11 (Fig. 10) a second barium meal after the primary examination

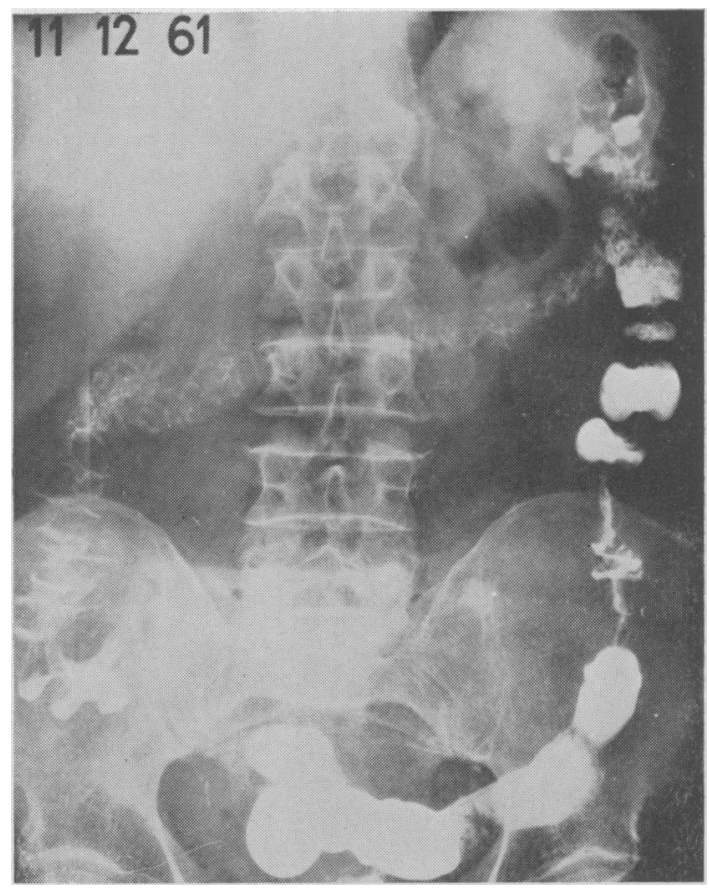

FIG. 1. Case 1: post-evacuation barium enema film showing gross thickening of gastric wall.

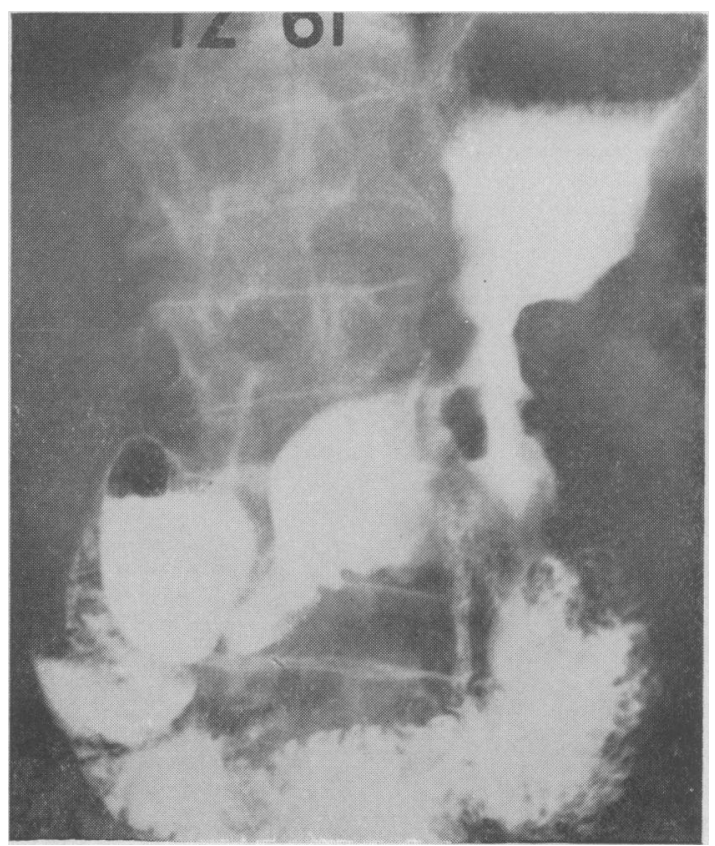

FIG. 2. Case 1: barium meal examination showing irregular constriction in the body of the stomach at the gastroenterostomy area. The fundus of the stomach is also abnormal. 


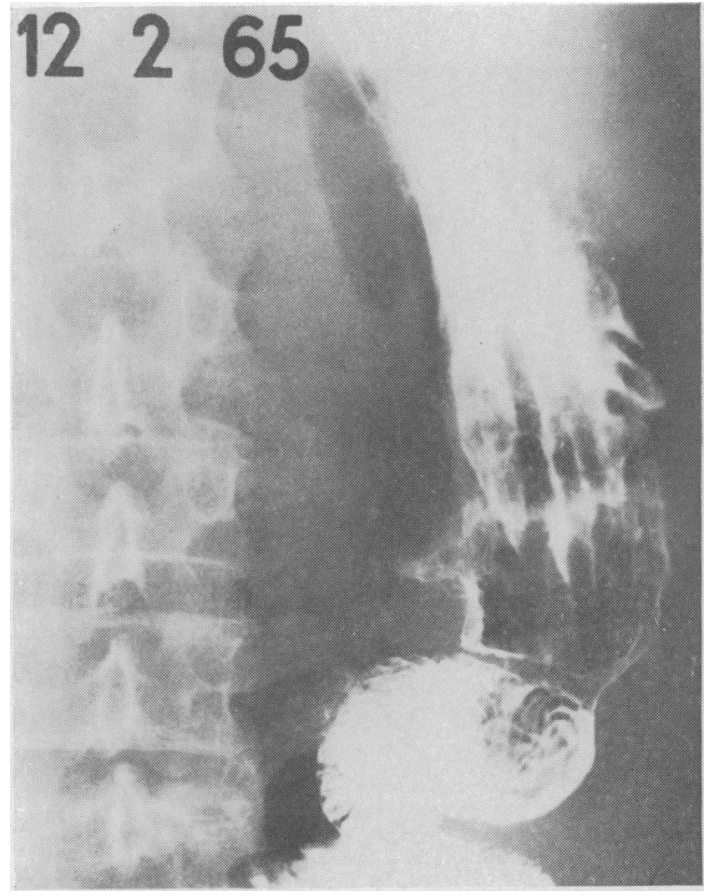

FIG. 3. Case 12: barium meal showing truncated conical antrum distal to normally functioning gastroenterostomy.

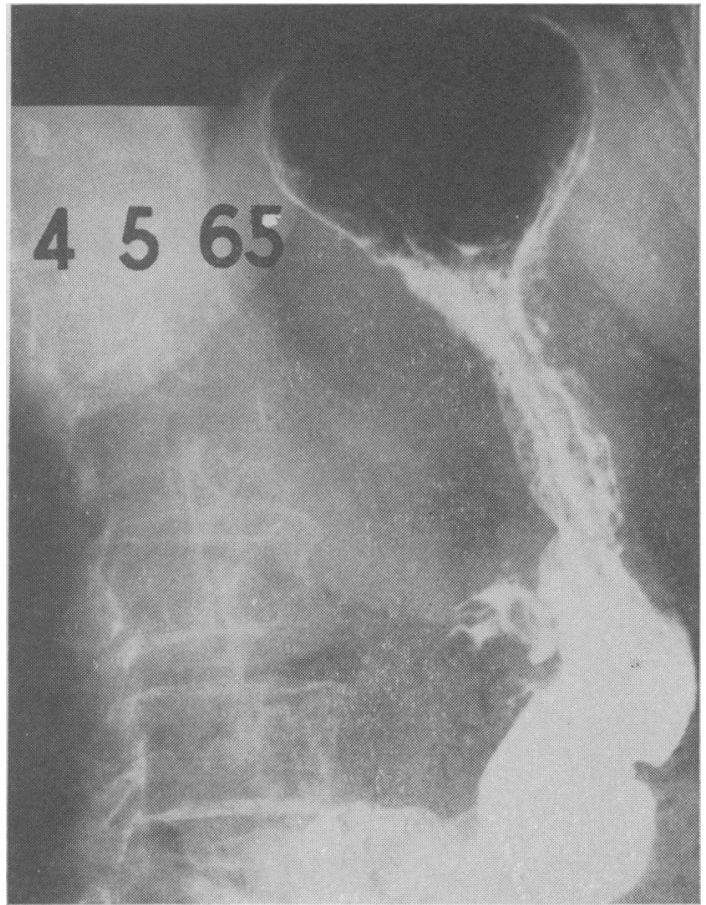

FIG. 5. Case 3: barium meal two years after Fig. 4, showing irregular filling defects in antrum. The stomach still empties freely through the gastroenterostomy stoma but not through the pylorus. Patient alive one year after partial gastrectomy.

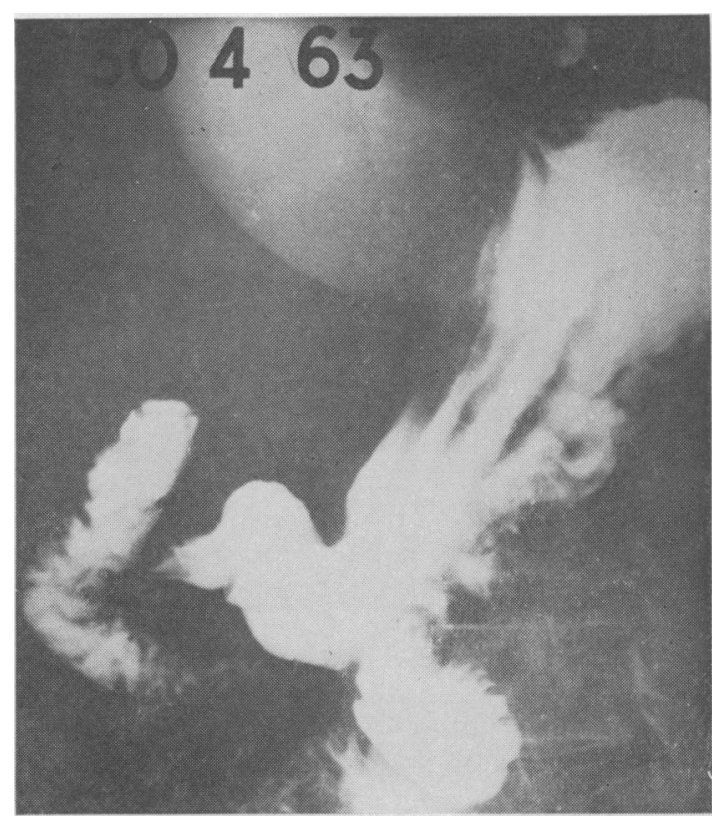

FIG. 4. Case 3: barium meal showing slight conical narrowing of the distal antrum. Stomach empties freely via pylorus and gastroenterostomy.

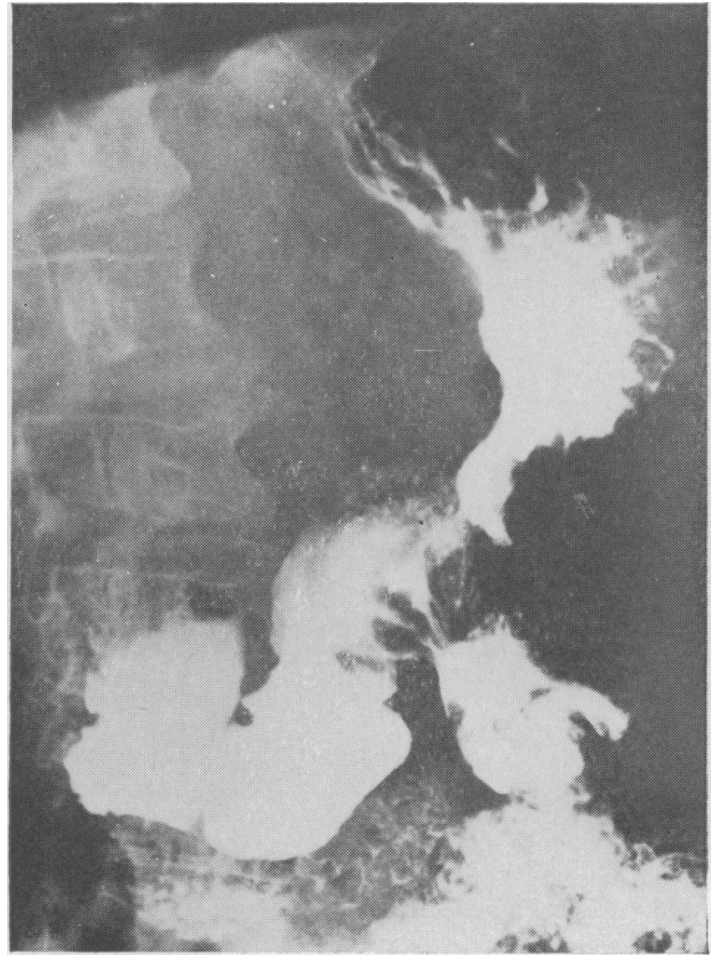

FIG. 6. Case 10: barium meal showing irregular constriction in the middle third of the stomach. Gastroenterostomy stoma involved but stomach still emptying via pylorus as well as through the stoma. 


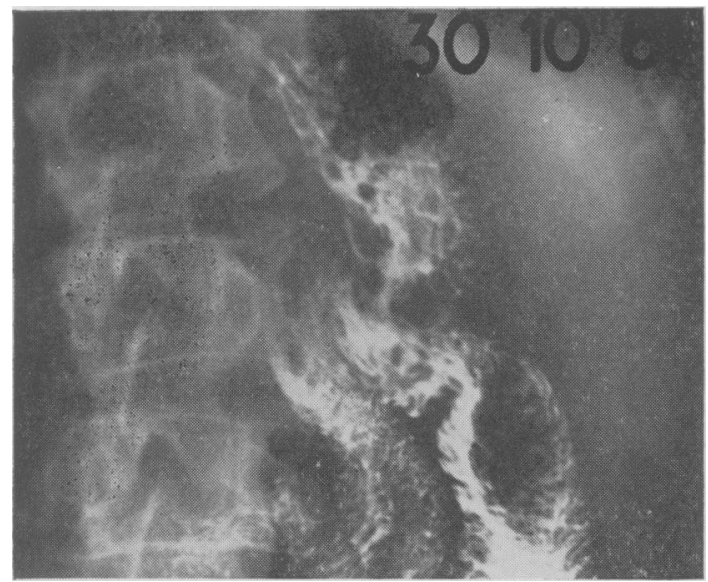

FIG. 7

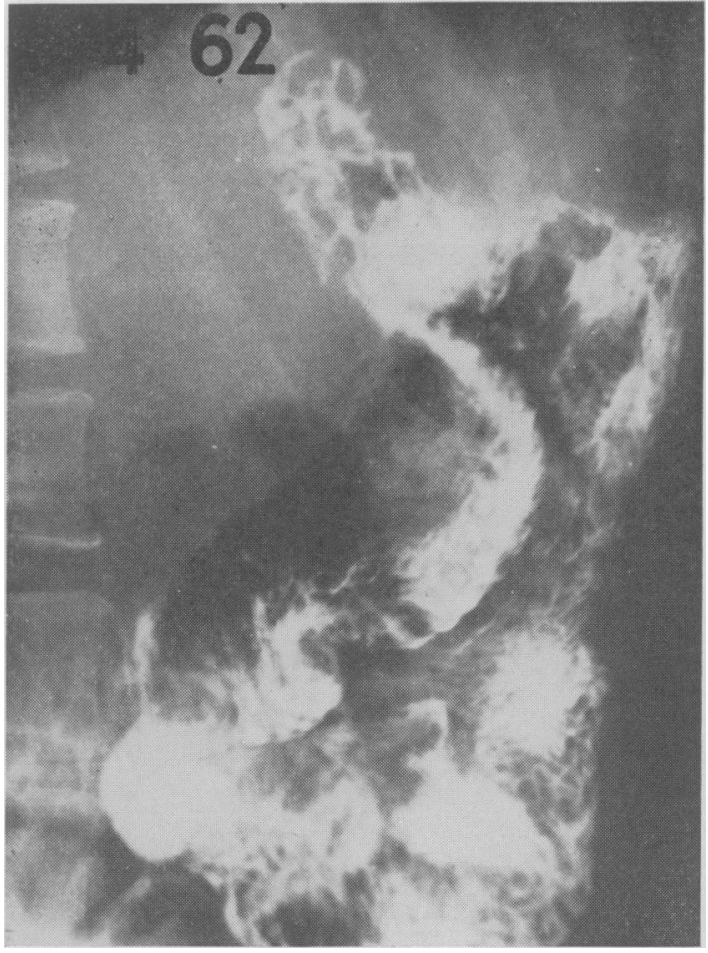

FIG. 8

FIG. 7. Case 2: Polya partial gastrectomy; the gastric rugae adjacent to the stoma appear rather coarse.

FIG. 8. Case 2: appearance six months after Figure 7. No real change.

FIG. 9. Case 2: appearances two months after Figure 8. 'Declared' total involvement of the whole of the gastric remnant. Linitis plastica type of appearance.

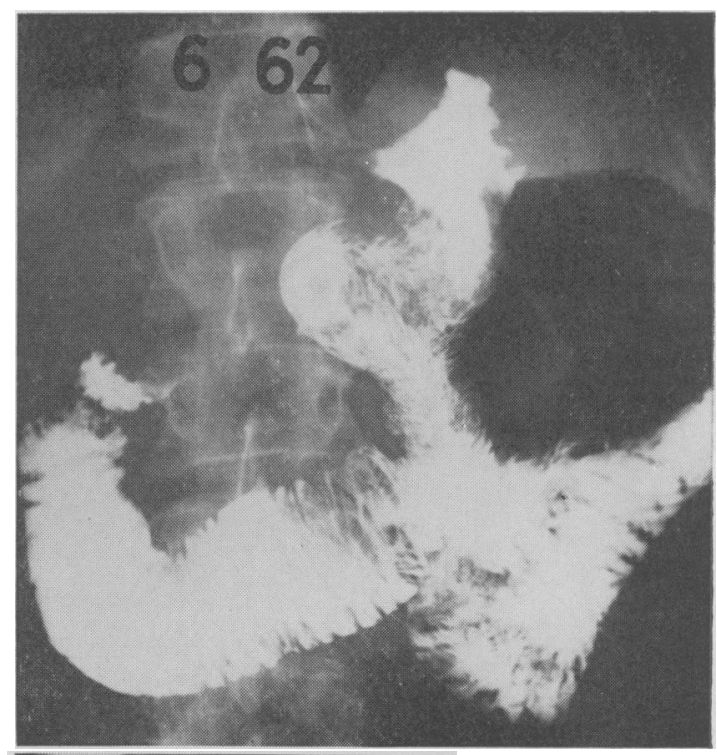

FIG. 9

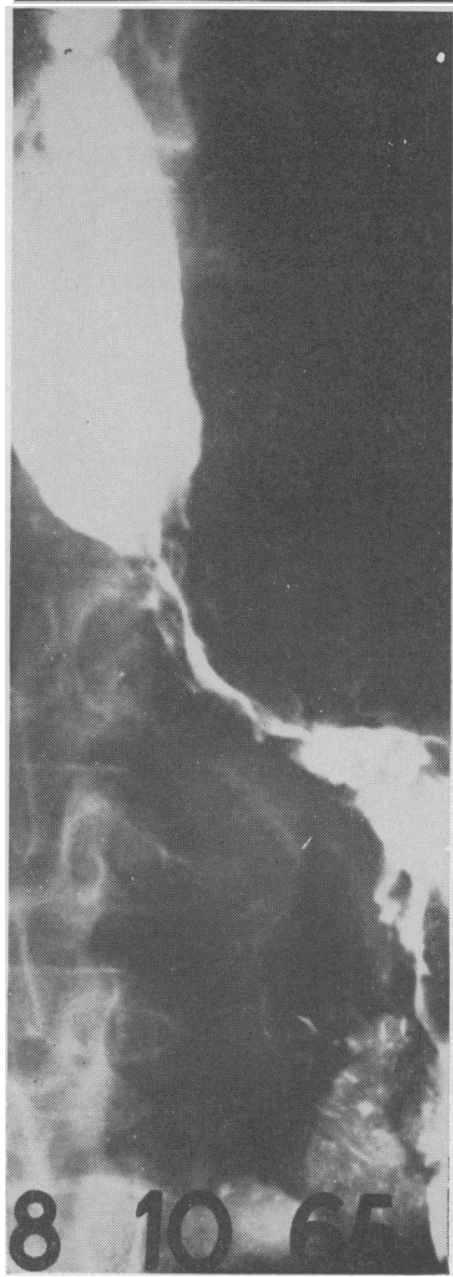

FIG. 10. Case 11: carcinoma involving the 'gastric sleeve' of the gullet. Carcinoma in Polya partial gastrectomy. Symptoms of oesophageal obstruction. 


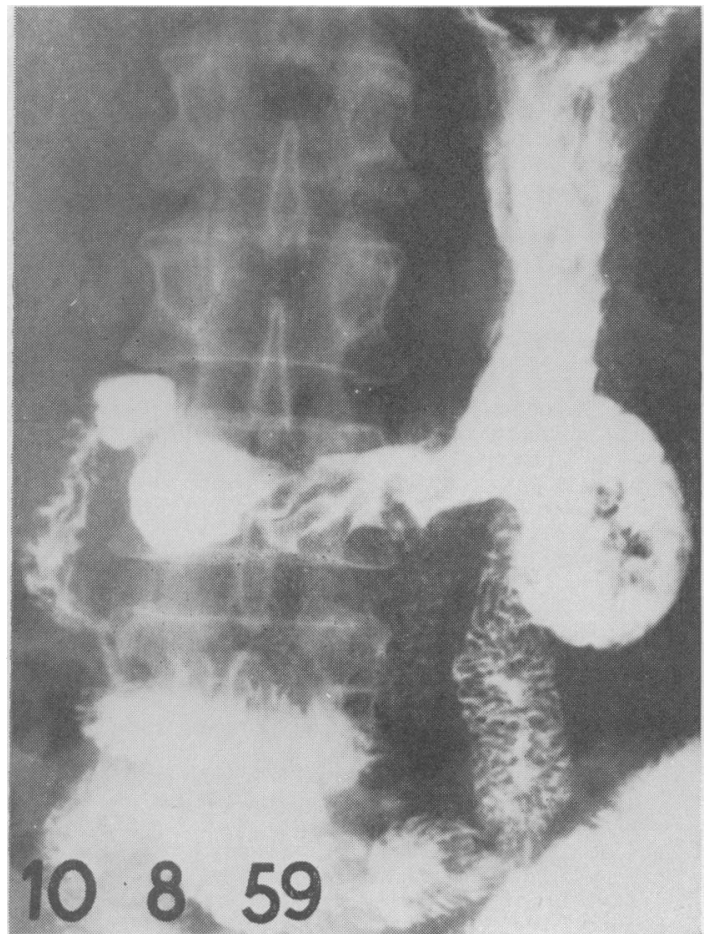

FIG. 11. Case 7: malignant ulcer (arrowed) in gastric antrum distal to gastroenterostomy. The associated infiltration extends well up the body of the stomach but both pylorus and stoma are functioning well.

was interpreted as showing peptic oesophagitis but operation revealed an extensive carcinoma of the lesser curvature of the remaining part of the stomach with secondary deposits in the liver from which the patient died two weeks later. In case 7 (Fig. 11) barium meal examination showed a large shallow neoplastic ulcer in the antrum distal to the gastroenterostomy stoma.

\section{DISCUSSION}

Our experience leads us to believe that the initial radiological examination will provide conclusive evidence in about $50 \%$ of the patients who develop gastric cancer after gastroenterostomy or partial gastrectomy. This corresponds with the experience of Pack and Banner (1958) but falls short of the claim made by Lecomte, Monges, Legré, Commandre, Giacobi, and Vedel (1965) who claim an accuracy of 22 out of 23 in personal cases. It is probably reasonable to say with Gerstenberg, Albrecht, Krentz, and Voth (1965) that radiology provides the most convincing evidence of gastric

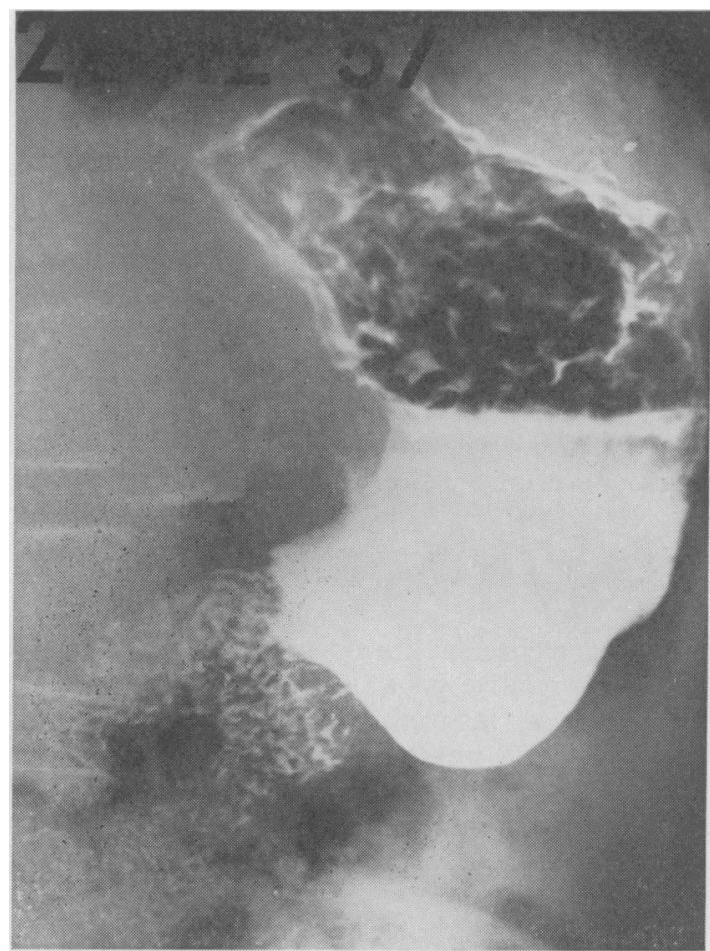

FIG. 12. Gastroenterostomy 17 years before for duodenal ulcer. Thought to have distal antral carcinoma partially obstructing the stoma. Alive and well nine years later. No operation.

stump carcinoma. Hoffmann (1960) comments upon the numerous problems of practical interest in those patients who have developed cancer of the stomach late after gastric operation. One of the radiological problems is to know with certainty what operation was in fact originally performed. We can echo the difficulty of Gray and Lofgren (1949) that it is almost impossible sometimes to know when a new lesion has developed in the portion of stomach distal to an old gastroenterostomy stoma. Thus Fig. 12 illustrates the appearance of the stomach of a man of 59 years who presented with recent symptoms 17 years after gastroenterostomy: the antrum was regarded as being carcinomatous but he is alive and well 10 years later.

In distinguishing neoplastic ulceration from simple stomal ulceration the information that the original operation was definitely for a gastric ulcer gives a strong bias towards the recent ulceration being neoplastic, since simple stomal ulceration is rare after partial gastrectomy for gastric ulcer (Edwards, Herrington, Cate, and Lipscomb, 1956; Thompson, 1956). Even after operation for duodenal ulcer 
simple stomal ulceration usually presents within three years of the gastric operation and is rare after a long interval so that this too should weigh in the radiological interpretation of suspicious cases.

Difficulty in distending the gastric remnant in a patient who has a rapidly emptying partial gastrectomy may make it difficult to exclude the presence of submucosal infiltration by carcinoma so long as the mucosal pattern retains a normal or near normal appearance.

It must not be forgotten that prolonged survival after the initial operation does not exclude the fact that a partial gastrectomy may have been for neoplastic ulcer of the stomach (Pygott, 1964).

\section{CONCLUSION}

The occurrence of gastric symptoms after a long period of relative good health in a patient who has had a partial gastrectomy or gastroenterostomy 10 or more years previously should suggest the need to exclude the development of cancer in the stomach. Radiological examination will provide conclusive evidence for the presence of carcinoma in $50 \%$ of the patients who are affected but this figure can be improved upon if the cause of the previous operation is known and it is realized that simple stomal ulceration presenting after many years' freedom from symptoms is rare. In a proportion of patients, perhaps $20 \%$, the diagnosis will only become clear as the result of further radiological examination after an interval.

Unfortunately, prompt diagnosis, as in other patients with gastric cancer, is not necessarily associated with satisfactory results following gastric resection, and delayed diagnosis, while regrettable, may on occasion be associated with more favourable operative findings and eventual prognosis.

As elsewhere, exfoliative cytology (Gibbs, 1962) may be of assistance in the diagnosis. Gastroscopy usually fails when radiology is also unsuccessful (Coffey and Cardenas, 1964).

\section{REFERENCES}

Aronson, A. R., and Darling, D. R. (1959). Carcinoma at the margin of the gastrojejunostomy stoma. Gastroenterology, 36, 686-690.

Beatson, G. T. (1926). Carcinoma of the stomach after gastro-jejunostomy. Brit. med.J., 1,15

Berkowitz, D., Cooney, P., and Bralow, S. P. (1959). Carcinoma of the stomach appearing after previous gastric surgery for previous benign ulcer disease. Gastroenterology, 36, 691-697.

Berry, T. J., Lee, T. C., and Coffey, R. J. (1959). Carcinoma arising in the gastric stump following resection for benign ulceration Amer. Surg., 25, 353-356.

Capos, N. J., and Hyman, S. (1961). Carcinoma in the residual stomach after gastric resection for duodenal ulcer. J. Amer. med. Ass., 177, 448-449.

Coffey, R. J., and Cardenas, F. (1964). Clinical features of carcinoma of the gastric stump following gastric resection for benign peptic ulcer. Amer. J. Gastroent., 42, 77-84.

Côté, R., Dockerty, M. B., and Cain, J. C. (1958). Cancer of the stomach after gastric resection for peptic ulcer. Surg. Gynec. Obstet., 107, 200-204.

Crohn, B. B. (1927). Affections of the Stomach. Saunders, Philadelphia.

Debray, C., Roux, M., Chevillotte, R., and Segal, S. (1950). Les cancers du moignon gastrique après gastrectomie pour ulcus. Arch. Mal. Appar. dig., 39, 702-716.

De Jode, L. R. (1961). Gastric carcinoma following gastro-enterostomy and partial gastrectomy. Brit.J. Surg., 48, 51 2-514.

Edwards, L. W., Herrington, J. L., Jr., Cate, W. R., Jr., and Lipscomb, A. B. (1956). Gastrojejunal ulcer: problems in surgical management. Ann. Surg., 143, 235-244.

Freedman, M. A., and Berne, C. J. (1954). Gastric carcinoma of gastrojejunal stoma. Gastroenterology, 27, 210-217.

Gerstenberg, E., Albrecht, A., Krentz, K., and Voth, H. (1965). Das Magenstumpf karzinom eine Spätkomplikation des opiererten Magens? Dtsch. med. Wschr., 90, 2185-2190.

Gibbs, D. D. (1962). Carcinoma in the gastric remnant after partial gastrectomy for benign ulceration. Gut, 3, 322.326.

Gray, H. K., and Lofgren, K. A. (1948). The significance of an ulcerating lesion in the stomach after gastro-enterostomy. Proc. Mayo Clin., 23, 454-460.

- - (1949). The significance of an ulcerating lesion in the stomach following gastroenterostomy. Surg. Gynec. Obstet. 89, 285-291.

Harbitz, H. F. (1952). Carcinoma of the stomach in patients previously operated on for gastric ulcer. J. Oslo Cy Hosp., 2, 140-143.

Helsingen, N., and Hillestad, L. (1956). Cancer development in the gastric stump after partial gastrectomy for ulcer. Ann. Surg., 143, 173-179.

Hoffmann, V. (1960). Magencarcinom nach Geschwürsoperation. Langenbecks Arch. klin. Chir., 295, 102-112.

Hurst, A. F., and Stewart, M. J. (1929). Gastric and Duodenal Ulcer. Oxford University Press, London.

Krause, U. (1958). Late prognosis after partial gastrectomy for ulcer Acta chir. scand., 114, 341-354.

Kühlmayer, R., and Rokitansky, O. (1954). Das Magenstumpfcarcinom als Spätproblem der Ulcuschirurgie. Langenbecks Arch klin. Chir., 278, 361-375.

Lecomte, P., Monges, H., Legré, M., Commandre, F., Giacobi, R., and Vedel, J. P. (1965). Aspects radiologiques des cancers du moignon gastrique après gastrectomie pour ulcus. J. Radiol. Électrol., 46, 557-561.

Leren, P. (1953). Carcinoma of the stomach in ratients with previous gastric resection. (In Norwegian). Nord. Med., 49, 741-742.

Liavaag, K. (1962). Cancer development in gastric stump after partial gastrectomy for peptic ulcer. Ann. Surg., 155, 103-106.

Owen, D. R. (1926). Carcinoma after gastro-enterostomy. Brit. med. J., 1, 825 .

Pack, G. T., and Banner, R. L. (1958). The late development of gastric cancer after gastroenterostomy and gastrectomy for peptic ulcer and benign pyloric stenosis. Surgery, 44, 1024-1033.

Packovich, M. J., and Beck, W. C. (1962). Carcinoma of the stomach subsequent to gastroenterostomy for duodenal ulcer. Guthrie Clin. Bull. (Sayre), 32, 60-65.

Pygott, F. (1964). Long survival after carcinoma of the stomach Gut, 5, 118-125.

Ryan, E. P., and Beal, J. M. (1957). The development of carcinoma of the stomach in patients with duodenal ulcer. Surgery, 42 , 271-275.

Singer, H. A. (1932). Carcinoma of the gastrojejunal stoma following operation for peptic ulcer. Arch. intern. Med., 49, 429-438.

Thompson, J. E. (1956). Stomal ulceration after gastric surgery. Ann. Surg., 143, 697-707. 